\title{
sciendo \\ MARKETING, START-UPS AND INNOVATION: A FRAMEWORK FOR UNDERSTANDING THE POSSIBILITIES FOR HARNESSING TECHNOLOGICAL INNOVATIONS IN TOURISM (BASED ON THE EXAMPLE OF THE GEORGIAN TOURISM SECTOR AND RUSSIAN START-UPS)
}

\author{
MARKETING, START-UPY I INNOWACJE: RAMY DLA ZROZUMIENIA MOŻLIWOŚCI \\ WYKORZYSTANIA INNOWACJI TECHNOLOGICZNYCH W TURYSTYCE \\ (NA PRZYKŁADZIE GRUZIŃSKIEGO SEKTORA TURYSTYCZNEGO I ROSYJSKICH START-UPÓW)
}

\author{
Dariusz Michał Trzmielak \\ University of Lodz, Management Faculty, \\ ul. Matejki 22/26 90-237 Łódź \\ Dariusz.trzmielak@uni.lodz.pl O ORCID: 0000-0002-4455-8845 \\ Devi Shonia \\ Sokhumi State University, Tbilisi \\ 61 Politkovskaya street, 0186 Tbilisi \\ Magdalena Skoneczna \\ University of Lodz, Management Faculty, \\ ul. Matejki 22/26 90-237 Łódź \\ magdalena.skoneczna2@uni.lodz.pl O ORCID: 0000-0002-3440-7357 \\ DOl: 10.2478/minib-2021-0011
}

\section{ABSTRACT}

The travel and tourism industry is one of the largest and fastest-growing sectors in the world. In the case of countries like Georgia, where tourism is a priority sector of the economy, innovation is crucial for a tourism-based development strategy - and this has become particularly important in the post-pandemic realities. This paper proposes a certain framework for understanding the possibilities for harnessing technological innovations in the travel industry (particularly apps and websites). It then considers the specific example of the country of Georgia, outlining the state's 


\section{ABSTRACT}

measures meant to foster IT innovation in tourism and also certain moderate successes to date in this respect. Next, the paper looks to Russian tourist-sector start-ups as models for operation that be successfully harnessed in the Georgian tourism industry, examining several such Russian start-ups in closer detail.

Key words: tourism, technological innovation, travel apps, fostering innovation

\section{ABSTRAKT}

Branża podróżnicza i turystyczna to jeden z największych i najszybciej rozwijających się sektorów na świecie. W przypadku krajów takich jak Gruzja, gdzie turystyka jest priorytetową gałęzią gospodarki, jej innowacyjność ma kluczowe znaczenie dla strategii rozwoju tego sektora. Innowacyjność w turystyce nabrała szczegónego znaczenia w realiach po okresie pandemii. Niniejszy artykuł przedstawia możliwości wykorzystania innowacji technologicznych w branży turystycznej (w szczególności aplikacji i stron internetowych). Następnie przedstawiono rozważania na przykładzie Gruzji, nakreślając działania państwa mające na celu wspieranie innowacji IT w turystyce, a także pewne dotychczasowe umiarkowane sukcesy w tym zakresie. W kolejnej części artykułu przedstawiono rosyjskie start-upy z sektora turystycznego jako modele działania, które z powodzeniem można wykorzystać w gruzińskim przemyśle turystycznym.

Słowa kluczowe: turystyka, innowacje technologiczne, aplikacje podróżnicze, wspieranie innowacji

JEL: M31, M38, O32, 038

\section{Introduction}

Tourism, as one of the world's fastest-growing industries (Matviyenko et al., 2015) and a developmental sector reflecting increasing personal income, leisure and mobility, has become one of the most important aspects of human spatial behaviour today. Travel and tourism are conducive to the creation of jobs for both highly qualified and unskilled individuals (Korinnyi and Tsyhanok, 2020); Kvartalnov, 2002; Pohuda and Rozmetova, 2019). This sector, unlike many others, has the potential to grow without major investments, offering multiplied benefits in terms of both income generation and employment. For many countries, therefore, tourism is a key industry in both the public and private sectors. 
The global tourism industry was certainly one of the first to make extensive use of new information technologies. The technical progress of the last thirty years has given rise to a highly innovative tourism sector, which can focus not only on its own organizational structure, but on relations with partner organizations, thus optimizing operating costs and increasing the ability to generate value for customers. Tourism is one of the significant fields of the economy in well-developed countries, prioritizing innovative processes that unify scientific, technical, and economic advances (Kotsan and Kyrilo, 2015).

Overall, tourism is a very broad sphere of innovative activity, constituting an intersectoral socio-economic system that includes not only accommodation but also transportation, communication, leisure, food and other aspects. Tourism not only creates new products, but also harnesses innovations introduced in other areas: such as the latest experience in the field of management, task implementation, and applications of recent scientific achievements and technologies put to use by the tourism market to improve products and services demanded by the market. Through the introduction of the latest advancements in informational technologies, the creation of tourist products, services, hotels, reservation of air tickets or other types of ticketing can all be taken to a qualitatively new level (Abbate et al., 2019).

The importance of tourism for modern economies is underpinned by the following circumstances:

1. Tourism is a complicated social-economic phenomenon, involving not only economic activity but also opportunities for regional and international cultural exchange and means for overcoming crisis situations.

2. Tourism is one of the most profitable and rapidly developing economic fields.

3. Tourism is characterized by a "high multiplier" effect, reflecting its extensive indirect impact on related fields of industry, e.g. transport, trade, etc. The World Tourism Organization, for instance estimates $^{1}$ that tourism has an indirect impact on more than 32 economic fields. 


\section{The determinants and trends in an innovation in tourism}

The determinants of innovation in tourism can be classified under three broad subheadings: innovation inputs (inventions, investments or activities that SMEs undertake in new services or product development); company characteristics (their capability to undertake innovation activities) and the environment (external factors that are beyond the control of the firm, such as law, the country's level of development, the infrastructure for transport and accommodation) (Van Nguyen et al., 2021). One of the major technological trends which is crucial for tourism development is online marketing. In many markets, online sales continue to explode. In the United States and Europe, more and more people are opting to do their shopping online rather than at brick-and-mortar stores (Kaplan, 2017; Marketo, 2017). DeMers (2017) forecasts that the trend towards cybershopping is likely to accelerate due to new technologies which are enriching the "online" shopping experience. Technologies supporting shopping, booking and social media coupled with artificial intelligence are analysing "big data" to create customer profiles which enable firms to create "market segments of one", at the individual level. In 2014, Stanford University launched a multi-million-dollar study of Artificial Intelligence (AI), issuing its first report on $\mathrm{AI}$ in 2016, which forecasts the impact of $\mathrm{AI}$ on eight industries. The most immediate impact of AI is likely to be on transportation, "Where a few key technologies have catalysed the widespread adoption of $\mathrm{AI}$ with astonishing speed. [...] Autonomous transportation will soon be commonplace [...] ...city-dwellers will own fewer cars [...]" (Trzmielak and Zehner, 2018). This all has an incremental impact on the tourism sector.

Another important trend that affects the development of tourism, in terms of the quality of tourism services, is smart mobility and smart city initiatives. The report of European Parliament mapping smart cities in the EU indicates the relationship between places with high levels of innovative and entrepreneurial activity with smart environment (Parris, 2020). There are many concepts of tourism service management - one of which would be based on the service models explored by Enoch, who proposed a fourfold service model typology: interchange service, network services, destination 
services and substitute services (Enoch et al., 2002, Potter, et al., 2020). Enoch's concept is applicable to the development of innovation in the tourism sector; in practice, it emphasizes the higher frequency of plane, bus and train services (e.g. autonomous vehicle technology) and self-check-in. Algorithms in phone applications can calculate the most efficient route for travel. One type that can now be found almost everywhere and is used in tourism involves chatbots, which can be quite helpful for any journey and can significantly facilitate tourist services. The tourism sector is characterized by a huge amount of interrelationships, services, data and information exchange. All this results in huge amounts of data being collected. With a wide variety of users, data-intensive technologies become necessary, making it possible to learn about travellers' behaviour, habits and needs (Li et al., 2018). Destination-specific services include the airport shuttles that operate to many world airports. The replacement of conventional transport also entails less noise and vibration, making transport more comfortable for tourists (e.g. mag-lev trains) (Vuchic, Casello, 2002).

Generally, in describing the impact of new technology on the tourism sector, many studies have focused on the business functions and tourism sectors. Therefore, studies indicate a significant role for technology applications and impacts in the hospitality, airline, intermediary, distribution, attraction, and Destination Management Organization (DMOs) sectors, with fewer studies on sectors representing events/festivals, cruises and other transportation players (Sigala, 2018). Many authors indicate as well that the new technologies are giving a considerable boost to fostering "smart tourism" (Bilotta, in press). The role of innovation in "smart tourism" can be seen in means of communication, decision support tools for firms, market intelligent sources for collecting, storing, analysing, sharing, visualizing and interpreting big data, e-learning tools for selfservice, automation tools, enabling new business models, transforming tourist experiences and co-creation platforms (Sigala, 2018). New technologies and services are critical to the long-term sustainability of tourism operators and particularly SMEs.

The introduction of innovation in modern tourism demands the following: the economic and political stability of the country, the existence of a current legislation base, an appropriate level of scientific-technical 
development, the existence of natural, financial and other necessary resources, and a certain level of infrastructural development. Current trends also must be well-analysed, including: demographic changes (aging population), lifestyles, the nature of the labour force, the frequency and duration of holidays, growing interest in new and unusual, non-standard experiences, etc.

Note also that in the modern tourism industry, the following trends are becoming increasingly evident as well:

- There is significant growth in trips to neighbouring countries and nearest regions as compared to more distant countries, which experts feel is connected to growth in the terrorism threat in the world, growth in the number of trips per year, growth in the distribution of holidays and a number of other factors.

- The economic benefits derived from tourism are growing increasingly clear and countries are taking an increasingly supportive attitude towards tourism, as expressed in the significant reduction of different barriers on their part. This provides for growth in the number of tourists in future and supports the current process of globalization.

- Constant growth in competition, both inside or outside the region, motivates the leading tourism companies to take broad and aggressive measures to continually stimulate their products.

- Growth in urbanization processes and densely inhabited regions has significantly encouraged the emergence of such new types of tourism as village tourism, short-term holidays, non-seasonal holidays, non-active forms of tourism, tours without living in hotels, eco-tours, hunting, etc.

- As a result of the introduction of informational technologies and the development of tourism operators' services, the world has become more informed and tourism much better studied.

- This trend will be developing in the future, giving rise to a new trend of travelling to less-known and hard-to-access locations for the purpose of seeking unique entertainment and unforgettable experiences.

Considering these factors and trends, tourism marketing should maximize the ability to harness all the opportunities available to it: natural conditions, multiple sightseeing locales, and cultural potential, combining 
previously unharnessed services into a united tourist package and offering new products to the market.

Marketing of innovations in the field of tourism considers the application of these new methods and techniques, implementing measures to support the formation of attractive and positive image of the country from the point of tourism within the world community. These must be systematic efforts which have a qualitative innovation, lead to positive developments, and ensure the stable formation and development of the sector. This may entail changes in processes, organization, marketing, products and so on, but it will have the effect of bolstering socio-economic development. Innovations in tourism require substantial material and financial outlays, making state support necessary.

Another significant tendency in tourism is related to sustainable development. Trips to locations off the beaten path and away from the given country's greatest tourist attractions, where one can enjoy peace and quiet and engage in close contact with nature are becoming more and more popular. A recently emerging trend of turning to local tourism is evident here. In recent years the fashion for trips to unusual places, such as houses floating on a lake or apartments situated in the treetops, has also been developing more and more. Websites are being created with databases of such unique accommodation, addressed to people looking for a bit more luxury and originality. Another trend that can be observed in the sustainable tourism industry (in Poland, for instance) is the organization of thematic trips, which typically involve some physical activity: this may include bicycle trips, family survival camps, culinary trips, selfdevelopment workshops, yoga weekends, sports trips and multi-day canoeing trips.

\section{The world tourism market and the impact on the Georgian tourism industry}

From the standpoint of development of innovations in the field of tourism, Georgia offers a very interesting example, where many measures have been implemented in this direction over the past 10-12 years. Georgia is among those countries of the world that derive a significant share of their 
income from tourism. In such countries where tourism is a priority sector of the economy, it is important to forecast what the tourism business can expect in the future, based on current changes in the country and distinctly defined trends.

Despite its small area $\left(69,700 \mathrm{~km}^{2}\right)$, Georgia is distinguished by rich natural and cultural resources and a unique biological diversity. Rare subtropical wetlands, semi-deserts, high alpine zones and snowy peaks can all be found in the country, just several hundred kilometres apart. There are more than 12000 historic and cultural monuments in the country and 4 of them are even listed as UNESCO World Heritage. Leisure tourists can choose from more than 100 resorts, sample mineral water from about 2400 springs, and enjoy the seaside. Nature lovers can visit the 8 national parks and 31 protected areas. The winter resorts of Gudauri, Bakuriani and Mestia promise visitors and skiers unforgettable days in winter and in summer.

In 1997 , tourism revenues amounted to $\$ 75$ million USD, or about $2.1 \%$ of the gross national product. At that time, this meant about 313,000 tourists and about $\$ 240$ per person. As Fig. 1 shows, the income from tourism has increased significantly over the last 22 years. In 2019, tourism revenues accounted for $20.32 \%$ of gross national product, or $\$ 3.55$ billion. 9.3 million international travelers have already arrived in Georgia by the end of 2019 (Georgian Journal, 2019)

The variety of reforms being implemented in Georgia in various aspects, the improvement of its economic and political stability, its gaining an image as a "country of reform" in the world and its making tourism development a priority industry in public policy have truly yielded results. Worth noting among the innovative activities implemented in Georgia are support for tourism infrastructure development, the facilitation of international travel, the improvement in service quality and awareness of the country, the implementation of marketing activities in both domestic and international markets, and development of tourism products. 
Figure 1. Tourism revenues as a percentage of Georgia's gross national product

5

0

ผ

Source: Created by the authors, based on https:/www.worlddata.info/asia/georgia/tourism.php

International tourism expenditures by international visitors are characterized by nearly exponential growth, confirming the great import of the tourism sector in Georgia (fFg. 2)

Figure 2. Georgia tourism receipts (International tourism, receipts (current US\$)

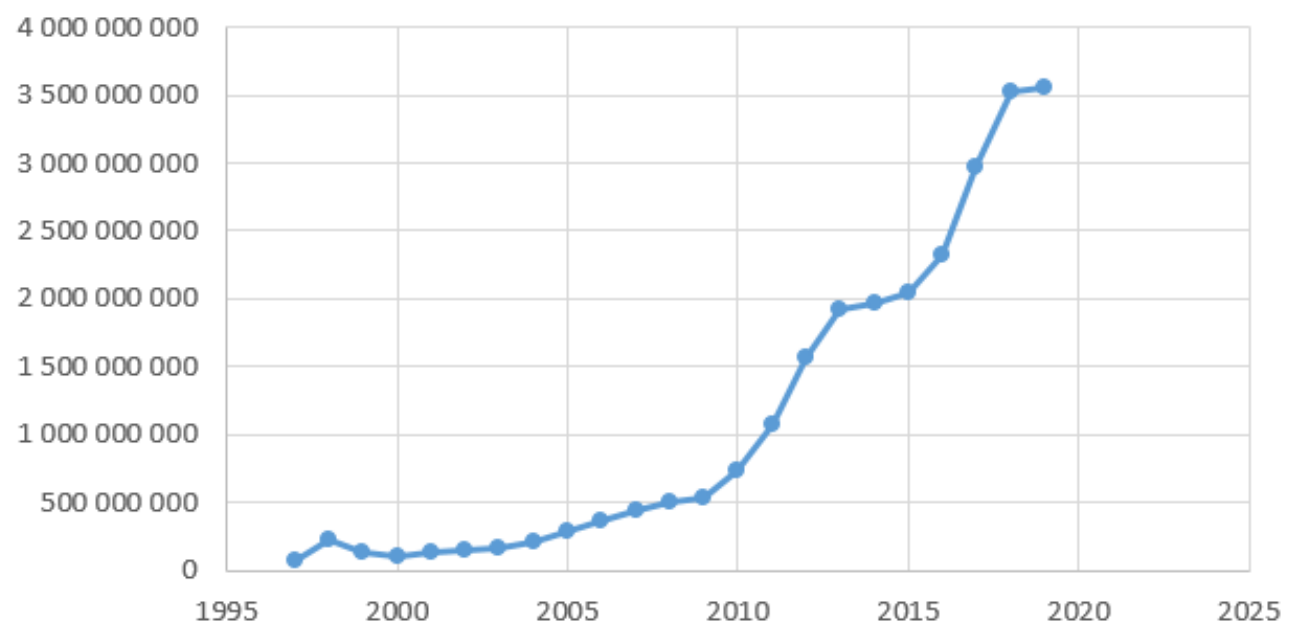

Source: Created by the authors, based on https://knoema.com/atlas/Georgia/Tourism-receipts 
With the objective of widening the investment opportunities in tourism infrastructure in Georgia, three free tourism zones have been set up, in Kobuleti, Anaklia and Ganmukhuri, offering preferential terms to investors: exemption from property tax and income tax obligations as set forth in the Tax Code of Georgia for a period of 15 years, exemption from construction permit fees. The investor of the land shall be transferred to the Georgian legislation, a symbolic price - 1 lari; When a hotel is built with more than 80 rooms, the investor will obtain a casino license for free. Investments in Georgian tourism sectors can be made in collaboration with the Partners Fund of Georgia, which offers financing and co-investment. Several successful projects have already been implemented in this way: the "Roialbatoni", "Gino Wellnes" and "Spa Rixos Borjomi" hotels, as well as the mineral-water resort Likani and a leisure complex in Sairme. ${ }^{2}$

The Georgian government has taken significant steps to boost the flow of tourists and has considerably eased visa regime. Citizens of 104 countries of the world have extended terms of visa-free entry and may stay in Georgia up to one year.. EU citizens can enter the country carrying a passport or identity card issued by the EU.

Georgia has become well-known for innovative projects implemented in tourism, not only in the region (as a leader country) but also throughout the world. In 2012 Georgia was mentioned in the report of World Tourism Organization (WTO). Its main annual publication - UNWTO Tourism Highlights - named it as one of the fastest growing tourist countries. The report estimated growth in travellers to Georgia at one of the highest rates in Europe as a whole. ${ }^{3}$

Georgia was ranked among the 50 best destinations by National Geographic Traveler (side by side with France, Italy, Portugal, Scotland, Switzerland, Sweden, Denmark) and its millions of readers were advised to travel in the country. ${ }^{4}$ Georgian cuisine, wine and culture was outlined. Georgia also ranks high as a country safe for travellers, placing among the top ten in the world. The country has hosted several international media forums, attended by journalists from many countries, who also had a chance to familiarize themselves with the country's cultural heritage, wine tourism, and ski resorts. They visited Tbilisi and a variety of resort 
centres in Sighnaghi, Tsinandali, Mtskheta, Gudauri, Gori, Tskaltubo, Akhaltsikhe and Batumi. The country hosted four meetings of the World Tourism Organization's (WTO) Silk Working Group, which was attended by delegates from 18 countries and representatives of the World Tourism Organization.

In recent years, many articles about Georgia have appeared in National Geographic, The New York Times, and The Guardian. CNN posted pictures of ancient Svaneti on its social network profile, and BBC journalists described the Svaneti villages as ranking among the legendary villages in Europe. An article was carried by the influential American edition of Bloomberg, where the writer advised readers to take a journey to Georgia, to sample Georgian wine. Many articles have also been published in the The Washington Post on Georgian wine and cuisine. Advertisements for Georgian wine are frequently run on Euronews, which has an audience of 400 million and broadcasts in 14 languages in 155 countries. Every year the country participates in approximately 25 exhibitions, where its tourism potential is promoted. The National Tourism Administration of the country carries carrying out a marketing campaign every year almost in 50 countriesand is conducting press tours.

With the aim of raising the quality of service, rigorous training is implemented for representatives of the tourism industry throughout the country. There is a hotline for tourists (0 800800 909), and a new "Online chat" service is being added, where tourists can obtain any information they request within 24 hours. The website www.georgia.travel has been revamped in line with demand, offering an updated and well-developed control panel, including the possibility of finding information via the "Google maps" application.

Despite of all these efforts, however, Georgia still faces a lot of problems in its tourism industry, especially in the regions. First of all, this stems from the infrastructure, particularly roads and transport. Prices are high in hotels offering the all-inclusive regime. The international air transport market requires more internal liberalization. The quality of customer service also requires further improvement. Lastly, tourists still have to pay significantly for quality accomodations in Georgia.

On the positive side, we should not that in order to facilitate the infrastructure for innovations in Georgia, at the end of 2020 the first 
technology park (industrial park) was opened, which should provide a suitably qualified workforce training, the necessary supporting infrastructure for R\&D and also promotion of full-cycle production - from idea to production.

\section{Start-up developments in the tourism industry - A chance for a rapid return to growth in Georgia}

Georgian tourism is an industry in which start-ups occupy an increasingly important place. Tourism start-ups seek to fill niches where it is difficult to succeed. Firstly, things are very competitive in the industry, with hundreds of travel agencies selling tickets and packages to any destination. Secondly, destination-oriented holiday bookings are often a one-off transaction, as few people travel to the same holiday destination each year. Moreover, most start-ups are based on IT solutions, regardless of the industry in which they operate. The key to the development and, above all, the survival of a start-up is the successful matching of the offered product or service to the appropriate target group.

The products of start-ups in the tourism industry are, in most cases, websites or applications (apps) that are dedicated to various groups of recipients, which can be grouped in terms of common features or preferences, which are key when choosing a way of traveling or spending free time. In this respect, the products of start-ups can be classified into several groups:

- Apps for people with disabilities, allowing for easier travel.

- Apps to increase travel safety by alerting tourists of potential scams and deceptions in various places, providing information on hospitals, doctors, and emergency points, and information on road assistance services in the event of an accident.

- Websites that help tourists with transport, e.g. to work or to tourist attractions.

- Apps that allow one to find travel companions - such applications can identify people traveling to the same place and using the same means of communication, who have similar travel preferences, thus helping to 
minimize travel costs.

- Concierge services - apps that help hotels provide additional services, such as b-Guest, or apps connecting communities that provide concierge services with travellers with payments built into the system.

- Trip planning apps and websites (by far the largest group of start-ups) such apps offer, for example, travel planning according to a set budget. Users set the time, place and budget, and the system searches for specific trips. By entering further information and choices about destinations, expectations etc, we end up with personally tailored sightseeing plans.

- Connecting travellers with locales and companies - this is a very large group of apps, designed to help travellers learn about local life in a given destination country/city. These applications can be very precisely tailored to target groups, e.g. applications that allow one to search for local private tours led by professional guides (linguoguides), portals for photography hobbyists (fripito), specific sports (guidebase), portals for ethnic groups, national minorities, sexual orientations (gaybrhood) ${ }^{5,6}$.

The goal of the Georgian government is to lay solid foundations for economic growth; to achieve this, Georgia, like many other countries, must focus on developing innovation. Start-up support, in turn, is one of the crucial factors of innovation policy, requiring the creation of an appropriate ecosystem to support innovators. To this aim, in 2014 the LEPL "Innovation and Technology Agency" was created under the Georgian Ministry of Economy and Sustainable Development, ${ }^{7}$ meant to promote this field in the country and create an innovation ecosystem. The purpose of the agency is to bolster Georgia's research infrastructure, to help foster innovations and new technologies, as well as to accelerate and facilitate the processes of knowledge commercialization. The agency also aims to increase the participation of private companies in the research and commercialization process, and to increase the share of venture capital in the process of investing in modern technologies. It initiates the basic directions of investment in infrastructure for innovation, supports the opening of innovation centres and industrial laboratories, technology parks (Gavtadze and Ipshiradze, 2016).

Public-private cooperation and a more well-developed technological ecosystem are making Georgia start-ups attractive to foreign investors. 
Due to its location, Georgia has always been a meeting place between Europe and Central Asia. Even before the creation of the ancient Silk Road, the country was a melting pot of peoples and cultures. Nowadays it is a very attractive country for new investors (Dugienko and Bondarenko, 2020). According to the World Bank, Georgia is the seventh easiest place to do business and the second easiest place to start a business. There are only six types of taxes, and for the IT sector things have recently become even easier, as international companies will have their income tax reduced to only 5\%. This is undoubtedly an incentive for tech companies, which can prove useful for start-ups. Georgia also offers infrastructure supporting the development of start-ups, such as co-working spaces or new business centres. These are places where big players from the financial markets are involved in development, e.g. Tbilisi City Hall and TechPark. 500 Georgia, a regional accelerator created by Georgia's Innovation and Technology Agency (GITA), the Bank of Georgia and 500 Start-ups with the support of the World Bank, is doing well. The program focuses on beginning start-ups from Georgia and Eastern Europe. In Georgia, business is well digitized, which is why start-ups based on high technologies are the most common. These are SaaS B2B start-ups related to various industries.

Unfortunately, however, this does not really apply to the tourism industry. Despite the fact that Georgia is an attractive tourist destination, this has unfortunately not translated into the digitization of the industry. The number of new technological solutions that are produced in Georgia ultimately for tourism is very small. This is also visible in the area of startups. $^{8}$

Be that as it may, a few successful examples are evident in the results of the Subsidy Program of the Agency for Innovation and Technology of the Ministry of Economy and Sustainable Development. A total of 20 winners were selected under the program. Several of them support the tourism industry: LiveCaller, ${ }^{9}$ Travel Guide, ${ }^{10}$ Phubber, ${ }^{11}$ and Atrion. ${ }^{12}$

Particularly noteworthy in this respect is Travel Guide, one of the few start-ups successively operating in the travel segment in Georgia. The Travel Guide app aims to fill the information gap for visitors to important landmarks around the world. The main goal of the company is to develop the tourism sector through the use of innovative technologies. It simplifies travel planning for customers and offers a full package of services. The 
platform includes audio files on landmarks, museums, points of interest and excursion routes. The platform offers audio recordings of local artists, poets and vocal groups. The offered tours can be adjusted by the user to their preferences, i.e. route length, duration, costs, topics, groups of visitors. All content is easily accessible via a state-of-the-art interface and can be equipped with GPS to deliver notifications if a user is near a featured site. The application provides audio and video content. The content is available in four languages: Georgian, English, Russian and Chinese. Thanks to this, the creators are continually expanding their audience. Travel Guide is led by an international team of "people of ideas" and programmers. Their goal is to expand the offer throughout Georgia and major European cities.

\section{Successful Russian start-ups for the Georgian tourism market}

The start-up ecosystem in Georgia is just emerging, but more and more companies are trying to create products with the global market in mind. This means it is worth looking at tourism-industry start-ups established, for example in Russia, ${ }^{13}$ to find models which could be successfully harnessed in the Georgian tourism industry. Several such start-ups offer excellent examples of such activities:

Chatme.ai offers ready-made and custom intelligent agents for various business functions in each industry. Chatme.ai has developed rich models of customer service, IT Service Desk, HR Helpdesk and services in BFSI, Telco, Logistics, Travel, etc. As a solution for the tourism industry, the company offers the use of artificial intelligence tools for effective communication with customers and employees of the hotel industry. For example, an AI-based travel chatbot that recognizes Russian can easily order a transfer or rent a car, check in for a flight, report the weather, and even chat with a customer about topics they choose. ${ }^{14}$

3Drimtim has created an IT solution for the museum business and socio-cultural projects. The project consists in creating a platform for the application of VR, MR and AR technologies in the field of culture with feedback through a neural interface. This solution is especially helpful for 
people working in museums who do not have technical knowledge and must perform activities such as archiving data, preserving exhibits, and demonstrating museum collections. In practice, this entails using virtual and augmented reality to create a virtual museum: anyone with the Internet can access the $3 \mathrm{D}$ gallery. ${ }^{15}$

Start-ups also offer solutions for the promotion of tourism and tourist destinations. One example is the company Neutrotrend, ${ }^{16}$ which is the largest Russian neuromarketing company with a wide range of solutions and research tools for various sectors of the economy. Neurotrend's business rests on a scientific basis, which opens up new possibilities for its customers to use neurotechnologies in marketing. The company has presented a solution based on the use of neuromarketing techniques to model product offers and communication in the tourism sector. The idea is to select the best tourist offer through synchronized registration of the client's psychophysiological reactions.

The start-up Republic offers intelligent solutions, namely smart tags in the form of a bracelet for tourists. The bracelet contains personal medical documentation in the cloud with a non-electronic identifier attached. Thanks to this, important information, e.g. on medications, diseases, allergies, and the attending physician, is always available to doctors in emergency situations involving a tourist. An interesting solution is the availability of data in 24 languages. In addition, the solution offers notifications about the user's location.

The Insurion ${ }^{17}$ project offers travellers automatic insurance - for example in the event of a flight delay or loss of a connecting flight. The insurer transfers customer data to Insurion. In the event of a flight delay, the insured person receives an SMS with a link, goes through the verification process, generates an electronic claim for insurance compensation and receives it for each hour of delay at the airport.

A fishing booking system is offered by the FishTravel ${ }^{18}$ start-up, which is designed to assist in booking fishing trips through the global booking platform. The service provides a range of services from booking a fishing trip, transport, accommodation, as well as guide. 


\section{Conclusions}

The tourism industry recognizes that it is indispensable nowadays to invest in innovative solutions in the field of information technology. New technologies should be implemented in all areas of the tourism sector, including museums, hotels, restaurants, gastronomy, transport, insurance, and medical services. Such efforts represent a big step towards the digitization of the tourism industry as a whole, and the emerging start-ups whose IT solutions are well tailored to support the flourishing of the industry in this respect are of particular importance.

This paper first proposed a certain framework for understanding the possibilities for harnessing technological innovations in the travel industry (particularly apps and websites). Because start-ups often make use of external sources of financing (Megha, 2017), typically derived from regional funds, their business profile must be linked to the development of the particular region or country the grant derives from, thereby determining their scope and area of operation. Hence, there is a visible trend to highlight the culture of a specific region or country.

In the ongoing COVID-19 pandemic, however, tourism has become a loss-making industry in all of the world's loss-making countries. This means that the industry is all the more in need of innovative ideas that respond to the clients focusing on local and often self-organized trips. New technologies have been quickly implemented in the sector, aimed at facilitating its growth. Whether growth proves possible will depend on the duration of the pandemic, the new restrictions imposed after the quarantine periods and the use of new technologies to facilitate the development of tourism.

All this is particularly true in the case of countries like Georgia, where tourism is a priority sector of the economy. State efforts to foster technological innovation are crucial for the success of a tourism-based development strategy — and this has become particularly important in the post-pandemic realities. This paper has considered the specific example of Georgia, examining its moderate successes to date in this respect (e.g. Travel Guide). Next, the paper has examined Russian tourist-sector startups. Several such Russian-created apps and websites were presented in closer detail (Chatme.ai, 3Drimtim, Neorotrend, Republic, Insurion, 
FishTravel) as potential models for operation that be successfully harnessed in the Georgian tourism industry.

Given that Georgia derives such a significant share of its income from tourism, its success in taking its economy towards post-pandemic recovery will hinge, in part, on its successful fostering of technological innovation in the travel sector and its harnessing of similar models to those discussed herein.

\section{Endnotes}

${ }^{1}$ http://www2.unwto.org/

2 https://www.fund.ge/site/news/63

${ }^{3} \mathrm{http}: / /$ www2.unwto.org/publication/unwto-annual-report-2012

${ }^{4} \mathrm{http} / /$ travel.nationalgeographic.com/travel/best-trips-2014/

${ }^{5} \mathrm{https}$ ://websummit.com/startups/featured-startups

${ }^{6} \mathrm{http}$ ://www.magelloapp.pl/web-summit-ciekawe-startupy-turystyczne.html).

${ }^{7}$ https:/gita.gov.ge/eng/static/3

${ }^{8} \mathrm{https}$ ://emerging-europe.com/voices/georgias-start-ups-are-ready-for-investment-time-for-vcs-to-take-note/

${ }^{9}$ A customer relations start-up that allows businesses to communicate for free with visitors to their website through internet calls, video calling, collaborative browsing, and correspondence.

${ }^{10} \mathrm{An}$ innovative tourism platform whose main goal is to develop the tourism sector by introducing innovative technologies.

${ }^{11}$ A ocial shopping platform - a mobile application that combines a social network and an online clothing store.

12 A program for organizations operating in the field of international development to be able to successfully implement international aid projects with less time and costs.

$13 \mathrm{https://www.atorus.ru/news/press-centre/new/44391.html}$

${ }^{14} \mathrm{https}: / /$ chatme.ai/

15 https://gadgets-room.ru/bs/klassifikaciya-informacionnyh-tehnologii-v-turizme-osnovnye-informacionnye/

16 https://neurotrend.ru/en/

${ }^{17} \mathrm{https}: / /$ eng.insurion.org/

18 https://fish.travel/

\section{References}

1. Abbate, T., Accordino P., Coppolino R., Tiziana La Rocca E., Rupo D., (2019). Innovative Tourism Startups: an Explorative Analysis. In: A. Jaki, T. Rojek (Eds) Knowledge Economy - Society: Contemporary Trends and Transformations of Economies and Enterprises, Torun: Polonia, 225-235.

2. Bilotta E., Bertacchini F., Gabriele L., Giglio S., Pantano P.S., Romita T., (in press). Industry 4.0 technologies in tourism education: Nurturing students to think with technology. Journal of Hospitality, Leisure, Sport \& Tourism Education. 1000275. 
3. Chokheli E. (2020). Developmental trends for startups in Georgia, Conference paper delivered at: 5th International Scientific and Practical Conference on "Strategic Imperatives of Modern Management" in Kyiv, April 2020.

4. DeMers, J. (2016). 7 New Technologies Shaping Online Marketing for the Better (We Hope). Forbes, August 15. https://www.forbes.com/sites/jaysondemers/2016/08/15/7-newtechnologies-shaping-online-marketing-for-the-better-we-hope/?sh $=479 \mathrm{e} 1 \mathrm{ddb} 61 \mathrm{fd}$

5. Dugienko N. A., Bondarenko A. G. (2020). The tourism industry as a way to growing the economy of the country (Georgia, Croatia, Ukraine). Bulletin of Zaporizhzhia National University: Economic Sciences, 2(46). https://journalsofznu.zp.ua/index.php/ economics/article/view/365

6. Enoch M., Potter S., Parkhurst G., Smith M. (2004). Internode: Innovations in Demand Responsive Transport. Manchester: Department for Transport and Greater Manchester Passenger Transport Executive.

7. Gavtadze G., Ipshiradze A. (2016). Some directions of scientific and innovative technological development of ATSU within the perspective of Georgia, Visnyk KNUTD, 440-447. ISSN 2413-0117;

8. Georgian Journal (2019). Number of international visitors to Georgia surge in 2019, 31 December.

9. Hansena M. Hjalagerb A. M. Fyall A. (2019). Adventure tourism innovation: Benefitting or hampering operations?. Journal of Outdoor Recreation and Tourism, 28, December. https://doi.org/10.1016/j.jort.2019.100253.

10. Kaplan, M. (2017). Sales Report: 2017 Thanksgiving Day, Black Friday, Cyber Monday. Retrieved on 1 December 2017 from https://www.practicalecommerce.com/sales-report2017-thanksgiving-day-black-friday-cyber-monday

11. Kotsan, N.N., Kurilo, O.A., (2012). Osnovnye osobennosti sovremenneogo razvitya tursma v Gruzii, Основные особенности современного развития туризма в Грузии, УДК 911.3:796.5(479.22); https://core.ac.uk/download/pdf/153584726.pdf,

12. Korinnyi S. O., Tsyhanok K. (2020). Current State of Tourism Business in European Countries and Its Trends. Bulletin of Zaporizhzhia National University: Economic Sciences, 2(46), 65-70.

13. Kvartalnov V. A. (2001). Turism [Tourism], 2002; Retrieved on 01.06.2021 from https://tourlib.net/books_tourism/kvartalnov_tourism.htm

14. Matviyenko N. M., Matviyenko V. M., Denisyuk Yu. M. (2015). Rozvitok Sil's'kogo Zelenogo Turismu v Khorvatiyi: Dosvid dla Ukrainy [Development of Rural Green Tourism in Croatia: Experience for Ukraine]. Chasopis Kartografiyi, 13, 98-109.

15. Megha J. (2017). Entrepreneurships and Startup Programmes: Opportunities in Travel and Tourism. ATNA, J. Tour. Stud., 12(2), 51-65, ISSN 0975-3281, https://doi:10.12727/ ajts.18.3.

16. Li J. Xu L. Wanmg S. Li L. (2018). Big data in tourism research. A literature review. Tourism Management. 68, 301-323.

17. Marketo (2017). Stark Contrasts in Technology Priorities for U.S. and International Marketers, Marketo Survey Finds. PRNewswire. Retrieved on January 12 from: https://www.prnewswire.com/news-releases/stark-contrasts-in-technology-priorities-forus-and-international-marketers-marketo-survey-finds-300390070.html and https:/www.i-scoop.eu/ new-technologies-marketing-2017. 
18. Parris S. (2020). Smart cities: locations for environmental entrepreneurship. In: W. J. Nuttall, D. V. Gibson, D. M. Trzmielak, A. Ibarra-Junez (Eds). Energy and Mobility in Smart Cities. London: ICE Publishing, 31-59.

19. Pohuda, N.V., Rozmetova, O.H. (2018). Sluchasnyi stan turistichnogo rynku Ukraiyiny: Ocenka ta perspektyvy rosvitku [Contemprary state of the tourist market of Ukraine: Evaluation and developmental prospects]. Efektivna Ekonomika, DOI: 10.32702/23072105-2018.10.57,2018, Retrieved on 01.06.2021 from: http://www.economy.nayka. com.ua/pdf/10_2018/59.pdf.

20. Potter S., Valdez A. M., Cook M. (2020). Autonomous vehicles and the urban mobility ecosystem, In: W. J. Nuttall, D. V. Gibson, D. M. Trzmielak, A. Ibarra-Junez, (Eds). Energy and Mobility in Smart Cities. ICE Publishing London, 83-98.

21. Sigala M., (2018). New technologies in tourism: From multi-disciplinary to antidisciplinary advances and trajectories. Tourism Management Perspectives, 25, 151-155.

22. Trzmielak D.M., Zehner W.B. (2018). Marketing of New Technologies and Products Perspectives, Challenges, and Actions. Handel Wewnetrzny, 5, 289-299.

23. Van Nguyen K., Natoli R., Divisekera S., (2021). Innovation and productivity in tourism small and medium enterprises. Tourism Management Perspectives, 38, 2-10, https://doi.org/10.1016/j.tmp.2021.100804

24. Vuchic R., Casello J. M., (2002). An Evaluation of Maglev Technology and its Comparison with High Speed Rail. Transportation Quarterly, 56(2), 33-49.

25. http://www2.unwto.org/, 01.06.2021

26. http://travel.nationalgeographic.com/travel/best-trips-2014/, 01.06.2021

27. http://www.magelloapp.pl/web-summit-ciekawe-startupy-turystyczne.html), 01.06.2021

28. http://www2.unwto.org/publication/unwto-annual-report-2012, 01.06.2021

29. https:/emerging-europe.com/voices/georgias-start-ups-are-ready-for-investment-timefor-ves-to-take-note/, 01.06.2021

30. https://eng.insurion.org/, 01.06.2021

31. https://fish.travel/, 01.06.2021

32. https://gadgets-room.ru/bs/klassifikaciya-informacionnyh-tehnologii-v-turizmeosnovnye-informacionnye/, 01.06.2021

33. https://gita.gov.ge/eng/static/3, 01.06.2021https://neurotrend.ru/en/, 01.06.2021

34. https://websummit.com/startups/featured-startups, 01.06.2021

35. https://www.atorus.ru/news/press-centre/new/44391.html, 01.06.2021

36. https://www.fund.ge/site/news/63, 01.06.2021 
Prof. (UL) Dariusz Trzmielak - holds PhD in management science at University of Lodz. His education was acquired at few universities: Middlesex University Business School in London, Warwick Business School, Justus -Liebig University in Giessen, Technological Educational Institution of Messolonghi. He completed director trainings (2003-2004) at the Innovation Creativity and Capital Institute at The University of Texas at Austin, where he was certified by the Institute as a knowledge and technology transfer specialist. He has published more than 100 scientific papers including 8 books (most recently Marketing New Yechnologies and R\&D Products, co-authored with William Bradley Zehner (USA), 2020) and 11 monographs by himself or with editorial co-authorship.

He is the author of more than eighty articles, the author or coauthor of seven books and the chief editor of eight monographs. He received the Management Faculty University of Lodz Dean Award for publication work and his book "New Product Development with Multidimensional Analysis". In 2013, he published the book "The Commercialization of Knowledge and Technology. Drivers and Strategies". In 2014, he got university professor degree. Prof. (UL) Dariusz Trzmielak is Head of Marketing Research Department at Management Faculty (University of Lodz) and the President Science Affairs Representative at Polish Mather's Memorial Hospital - Research Institute (Lodz). Chairman of the Audit Committee at Polish Business and Innovation Center Association

Scientific interest: Management of new technologies, marketing of new technologies and R\&D products, knowledge and technology transfer, cooperation of science, business support centres and entrepreneurs, intellectual property and market research of new technologies, assessment of the economic value of new technologies.

Devi Shonia - Ph.D. Associate Professor at the Faculty of Business and Social Sciences, Sukhumi State University, Tbilisi, Georgia. In 2016, within the Mobility Erasmus Program, he was a post-doctoral fellow at the Faculty of Management of the University of Lodz. Teaches training courses: "Basic of Marketing", "Consumer Behavior", "Strategic Marketing". He is the author of over 20 scientific articles and two textbooks (in Georgian).

The main research area: Marketing research, analysis, modeling, and implementation of strategies of innovative products and brand development. Devi Shonia is a member of the editorial board of journals: "Business and Management" (Georgia) and "Marketing of Scientific and Research Organizations" (Poland). Also, he is a member of the Academic Council of Sukhumi State University and a member of the Expert Corps for the Quality Development of Higher Education in Georgia.

Magdalena Skoneczna - (Master of Engineering) is a PhD student at the Marketing Department at the Faculty of Management at the University of Lodz. He is a specialist in the field of obtaining European funds and project management. For several years, she is the coach the following areas: entrepreneurship, business management, EU fundraising, project management, IT issues, ECDL examiner. She is the Head of the Scientific And Research Cooperation Department at Polish Mather's Memorial Hospital - Research Institute (Lodz, Poland).

Scientific interest: EU funds, startups, new technologies, research commercialization, cooperation of science, business support centres and entrepreneurs, intellectual property and market research of new technologies. 